\title{
Assessment of sábalo (Prochilodus lineatus) fisheries in the lower Paraná River basin (Argentina) based on hydrological, biological, and fishery indicators
}

\author{
Claudio Baigún ${ }^{1}$, Priscilla Minotti ${ }^{2}$ and Norberto Oldani ${ }^{3}$
}

This study assesses the change in fish exploitation patterns of the sábalo fisheries of the lower Paraná River basin based on hydrological, biological, and fishery indicators. From historical catch records, we recorded a shift from a lightly and moderate exploited status before 2001 to a heavily exploited one, as a result of the development of sábalo exports from 2001 onwards. Channel and floodplain connectivity indices demonstrated that the Paraná exhibited highly favorable hydrological conditions between 1972 and 1999 but more adverse conditions from 1999 to 2009, as a consequence of flood pulses reduction coincident with a fishing mortality increment. A total catch of 15,000 tons, including local consumption, regional market, informal sales, and exportation volumes, was estimated as the maximum sustainable catch. That level was instead exceeded 3 fold in 2004, in parallel with a decrease in the mean fish length from 48 to $42 \mathrm{~cm}$, along with a reduction in both the mesh size from 16 to $12 \mathrm{~cm}$ and megaspawner proportion, and an increase of fishing mortality. Although growth overfishing was not noted, an analysis of the spawning potential ratio trend indicated that recruitment overfishing took place during 2005 , since the fishing mortality rate was 4 times greater than the natural mortality rate. These observations suggest that less favorable hydrological conditions after 1999 coupled with a coincident high fishing pressure could have impacted the sábalo population biomass. Management of sábalo fisheries requires to set aside a single economic vision of the resource use moving to an ecosystem-oriented approach that incorporate, among others components, the hydrological regime, species life history traits, fishing impacts on other species, and main stakeholders socioeconomic requirements as key elements for the preservation of fishery sustainability.

Este estudio evalúa el cambio en los patrones de explotación de las pesquerías de sábalo (Prochilodus lineatus) en la baja cuenca del río Paraná basado en indicadores hidrológicos, biológicos y pesqueros. A partir de registros históricos de capturas se notó un desplazamiento de un estado de explotación ligera o moderada previa a 2001 a otro de explotación intensiva como resultado del desarrollo de una pesquería para exportación a partir de ese año. Los índices de conectividad hidrológica demostraron que el Paraná exhibió condiciones muy favorables para el sábalo entre 1972 y 1999, pero más adversas entre 1999 y 2009 al reducirse el caudal, que coincidió con un aumento en la mortalidad por pesca. Se estimó en 15.000 toneladas la captura máxima sostenible, incluyendo tanto la destinada al consumo local, venta informal y en mercados regionales, como la asignada a exportación. Este nivel, sin embargo, se triplicó en 2004, siendo acompañado por una disminución de la talla media y máxima de captura de 48 a $42 \mathrm{~cm}$ y de 64 a $58 \mathrm{~cm}$ respectivamente, una reducción de abertura de malla de 16 a $12 \mathrm{~cm}$ y un descenso en la proporción de megareproductores. Aun cuando no se detectó sobrepesca de crecimiento, el análisis de la tendencia de cambio del cociente de desove potencial muestra que hubo sobrepesca de reclutamiento en 2005, con stocks sobrepescados debido a que la tasa de mortalidad por pesca excedió en 4 veces la tasa de mortalidad natural. Estas observaciones sugieren que la existencia de condiciones hidrológicas menos favorables a partir de 1999, coincidentes con una elevada presión de pesca, pudieron haber impactado sobre la biomasa de esta especie. El manejo de esta pesquería requiere dejar de lado la visión exclusivamente economicista de uso del recurso y adoptar un enfoque ecosistémico que incorpore, entre otros componentes, el régimen hidrológico, los rasgos de vida de la especie, y los requerimientos socioeconómicos de los diferentes actores como elementos claves para conservar la pesquería del sábalo en niveles sostenibles.

Key words: Artisanal fisheries, Flood pulse, Neotropical rivers, Overfishing.

${ }^{1}$ Universidad Nacional de General San Martín, Instituto Tecnológico de Chacomús (IIB-INTECH-CONICET). Av. Intendente Marino, Km 8.3, C.C. 164,(7130), Chascomús, Argentina. cbaigun@gmail.com

${ }^{2}$ Universidad Nacional de San Martín, Instituto de Investigación e Ingeniería Ambiental, Laboratorio de Ecología Teledetección y Ecoinformática (LETyE-3iA-UNSAM). Peatonal Belgrano 3563 (1650) Gral. San Martín, Buenos Aires, Argentina.

${ }^{3}$ Centro Científico Tecnológico, Güemes 3450 (3000) Santa Fe, Argentina. 


\section{Introduction}

Fishery management in the South American large floodplain rivers is becoming a relevant and demanding issue. These river networks provide a considerable variety of ecosystem goods and services to human society, with the fisheries therein being one of their most valued attributes. Small scale fisheries as those normally found in these large rivers play a critical role in local livelihoods in the way of providing food sources and a relief from poverty (Berkes et al., 2001; Béné et al., 2006). In recent years, however, an increase in the fish catch in large South American rivers has been recognized as a potential source of the overexploitation of several migratory stocks (Novoa, 1989; Isaac \& Ruffino, 1996; Quirós, 2004; Petrere et al., 2004; Fabre \& Barthem, 2005; Galvis \& Mojica, 2007).

In the lower Paraná basin, the second largest in South America, artisanal fishing is a traditional activity that provides most of the commercial catches within that region. The sábalo - a species that represented up to $60 \%$ of the fish biomass in the floodplain lagoons (Bonetto et al., 1970; Tablado et al., 1988) - is by far the main target (Quirós \& Cuch, 1989; Baigún et al., 2008). During the last decade, however, the problems of the fisheries have been exacerbated as a result of the installation of several cold storage plants, after 2001, for commercial fishery development so as to promote changes in the exploitation patterns and resource uses. Those conditions have increased the fishing effort in the absence of appropriate regulations, thus generating stakeholder conflicts and promoting stock reductions that were apparently not detected because of the lack of suitable indicators.

Despite the significance of the sábalo fisheries in the Paraná basin, most of the previous studies directed at sábalo population assessments have been focused exclusively on the biological features, as reviewed by Sverlij et al. (1993). Quirós \& Cuch (1989) presented a broad picture of catch trends, although not considering the exportation period, whereas Espinach Ros \& Sanchez (2006) and Espinach Ros (2008) assessed first results after exportation fishing increased, improving also relevant biological information. Lack of a comprehensive analysis, however, is not surprising since only rough landing records are available, and additional relevant fishing parameters - such as effort, catch per unit effort and length structure data - were almost not collected on a long term temporal basis. In absence of suitable information, several indicators could be applied to assess fishery status and trends. The development of valid indicators and their respective reference values, however, still represent a major challenge for large river fisheries as the Paraná, due to the current lack of reliable fishery information and the expected dependence of species abundance on the hydrological regime.

In this study we assess the impact of the intensive fishing development on the sábalo stocks after 2001 and compare with previous fishing conditions and exploitation levels using different biological, fishery and hydrological indicators. Based on these analyses, we propose several reference points to serve as guidelines for sustainable adaptive management.

\section{Material and Methods}

The study site covers an area of about $10,000 \mathrm{~km}^{2}$ of the lower Paraná River including its Delta region, from Helvecia to Victoria ports (Fig. 1). This region includes an extensive complex floodplain, with main and secondary river channels connected to numerous shallow lakes, where $8,000 \mathrm{~km}^{2}$ can be considered as available for fishing during hydrological conditions characterized by average yearly floods. The main hydrological and geomorphological features were described by Baigún et al. (2008) for the Delta and by Drago (2007) for the middle Paraná.

Landing records and resource use. Landing records from 1935 to 1994 were extracted from the Dirección Nacional de Pesca Continental, Argentina (National Agency of Freshwater Fisheries). Data prior to 1935 were not considered reliable and therefore were not included in the long term average captures. No data were available from 1988 to 1993. From 1995 to 2009 , records corresponded only to exports and were

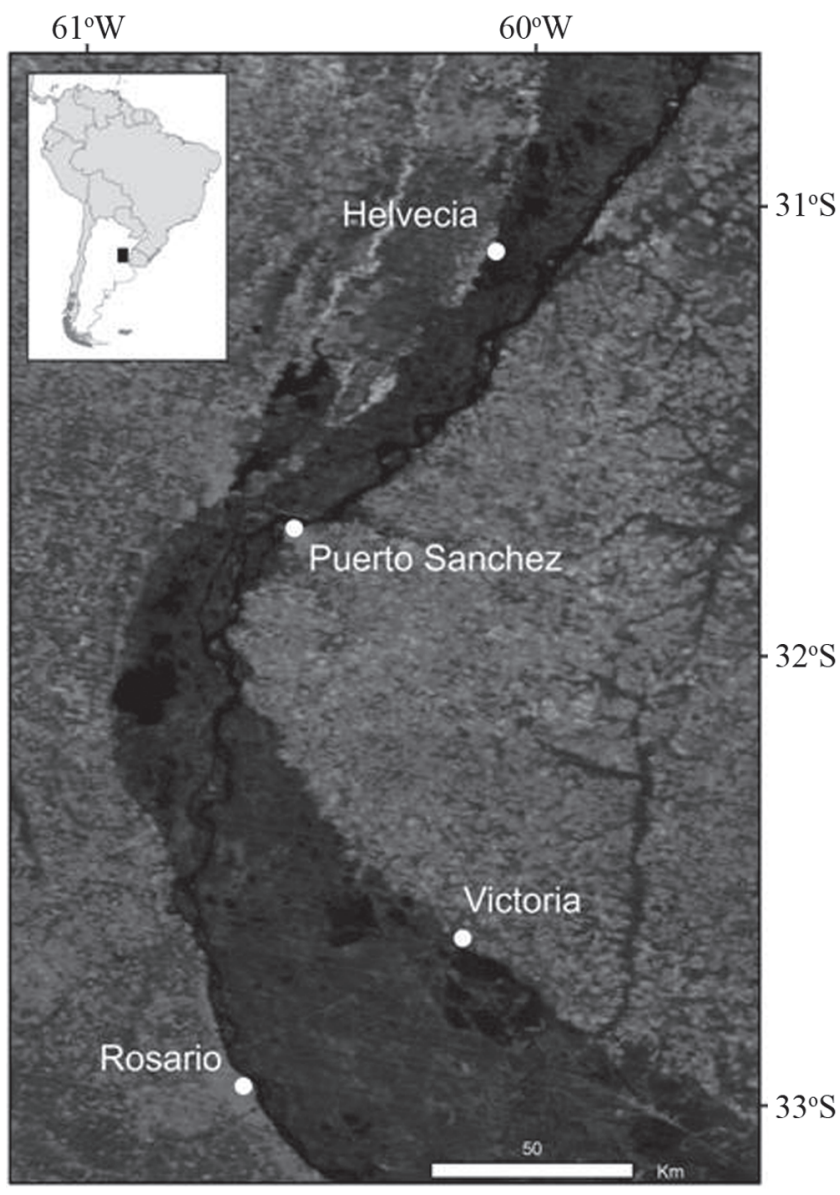

Fig. 1. Study area and the location of the main landing sites of the sábalo fisheries in the lower Paraná basin. 
provided by the SENASA (National Service of Animal Health, Argentina). Based on local authorities and fishery biologist estimations, we considered an average catch of 5,000 tons per year, which corresponds to local consumption and local market sales. This value was added to all years to estimate the total catch.

Habitat hydrological indicators. Historical yearly flow records and daily water level data from 1935 to 2009 at Paraná city were obtained from the Subsecretaría de Recursos Hídricos (Argentina). We developed two habitat hydrological indices as proxies of nursery habitat accessibility and permanence during sábalo larvae growing period. Such analysis comprised water level records from October to March, corresponding to the reproductive and the critical larval growth period season. These habitat indices were as follows:

a) Channel connectivity index (CCI): This index defines the percentage of days within the October through March period (182-183 days) that the water level surpasses the bankfull level $(3 \mathrm{~m})$, therefore connecting the main channel to the floodplain.

b) Floodplain connectivity index (FCI): Defines the percentage of days from October through March (182-183 days) when water surpasses $4.3 \mathrm{~m}$ and the entire alluvial valley becomes completely flooded.

Fishery data and yield estimation. The general fishery and population data were either collected directly or estimated from Boivin \& Minotti (1990), Dománico \& Delfino (1998), Oldani et al. (2005), and Espinach Ros \& Sánchez (2006); with those data being based on fishery population surveys and analyses performed in the basin during different years.

The maximum sustainable yield (MSY) was estimated following the guidelines of Welcomme (1985), who had assessed the MSY of subtropical floodplain rivers to be 40$60 \mathrm{~kg} / \mathrm{ha}$. In the present study the middle and lower Paraná River was assumed to support a lower yield than subtropical and tropical regions because the area through which the river mostly runs is temperate. Therefore, we selected $40 \mathrm{~kg} / \mathrm{ha}$ as the expected maximum catch (MC), but also considered 30 $\mathrm{kg} / \mathrm{ha}$ as a reliable value based on the estimation of Welcomme et al. (2006) of $28 \mathrm{~kg} / \mathrm{ha}$ for Latin American large river floodplains. Thus, the sábalo MSY was estimated as follows:

\section{$\mathrm{MSY}=\mathrm{MC} \times \mathrm{CA} \times \mathrm{SF} \times \mathrm{SL}$}

where $\mathrm{MC}$ was considered as $30 \mathrm{~kg} / \mathrm{ha}$ to $40 \mathrm{~kg} / \mathrm{ha}$, CA represents the catch areas used by sábalo fisheries $(800,000$ hectares), SF is a species abundance factor considered as 0.6 by Bonetto et al. (1978) to correct for sábalo relative abundance, and SL represents a factor - usually fixed as $2 / 3$ to provide a safeguard limit against either potential density independent effects on recruitment or recruitment variability (Gulland \& Boerema, 1973).

\section{Population parameters.}

a) Growth parameters: The asymptotic length $\left(\mathrm{L}_{\infty}\right)$ was estimated by the equation of Froese \& Binohlan (2000):

$$
\log \mathrm{L}_{\infty}=0.044+0.9841 \log \mathrm{L}_{\text {max }}
$$

where $\mathrm{L}_{\max }$ is the maximum length, here considered as 66 $\mathrm{cm}$ according to 1978 fishery records performed in the area by Oldani et al. (2005). The growth rate (K) was determined by the equation proposed by Froese \& Binohan (2003):

$$
\mathrm{K}=-\ln \left(1-\mathrm{L}_{\mathrm{m}} / \mathrm{L}_{\infty}\right) /\left(\mathrm{t}_{\mathrm{m}}-\mathrm{t}_{0}\right)
$$

where $\mathrm{L}_{\mathrm{m}}$ and $\mathrm{t}_{\mathrm{m}}$ represent the size and age, respectively, at first maturity and $t_{0}$ is a parameter expressing the theoretical age in years the fish would have had at length zero under conditions of growth according to the von Bertalanffy function. This parameter was fitted by the iterative procedure proposed by Froese \& Binohlan (2003).

b) First size at maturity $\left(\mathrm{L}_{\mathrm{m}}\right)$ : This parameter represents the length at which $50 \%$ of population becomes matured. To estimate this value the following equation was used (Froese \& Binohlan, 2003):

$$
\log \mathrm{L}_{\mathrm{m}}=0.8979 \log \mathrm{L}_{\infty}-0.0782
$$

c) First size at $100 \%$ maturity $\left(\mathrm{L}_{100}\right)$ : This parameter, indicating the size at which $100 \%$ of the population has reproduced, was estimated by the following equation (Froese and Binohlan, 2003):

$$
\mathrm{L}_{100}=\mathrm{L}_{\mathrm{m}}+\left(\mathrm{L}_{\infty}-\mathrm{L}_{\mathrm{m}}\right) / 4
$$

d) Instantaneous natural mortality (M): Natural mortality was computed from the following different empirical relationships recognized in the literature and based on fundamental bionomic characteristics:

Pauly (1980):

$\log _{10} \mathrm{M}=-0.0066-0.279 \log _{10} \mathrm{~L}_{\infty}+0.643 \log _{10} \mathrm{~K}+0.4634 \log _{10} \mathrm{~T}$

where $\mathrm{T}$ is the mean water temperature, considered as $22^{\circ} \mathrm{C}$ according to Drago (1984), and $\mathrm{L}_{\infty}$ and $\mathrm{K}$ the von Bertalanffy parameters,

Hewitt \& Jones (2005):

$\mathrm{M}=2.996 / \mathrm{t}_{\max }$

with $\mathrm{t}_{\max }$ being the maximum age observed in the stocks and obtained from Espinach Ross \& Sanchez (2006) as 11 years,

Rikhter \& Efanov (1976):

$\mathrm{M}=1.521 /\left(\mathrm{T}_{50}{ }^{0.72}\right)$

where $\mathrm{T}_{50}$ - the age at which $50 \%$ of the population is mature - was considered as 2.6 years, with this value having been obtained by the von Bertalanffy equation,

Jensen (1996):

$\mathrm{M}=1.5 \mathrm{~K}$

where $\mathrm{K}$ corresponds to the von Bertalanffy growth rate,

Alagaraja (1984):

$\mathrm{M}=-\ln (0.001) / \mathrm{t}_{\text {max }}$

where $t_{\text {max }}$ is the maximum age observed in the stock. 


\section{Fishery indicators.}

a) Mean and maximum fish length: These parameters were considered indicative of demographic changes produced by fishing mortality in exploited stocks. The mean and maximum lengths were obtained from the survey records of Boivin \& Minotti (1990), Dománico \& Delfino (1998), Oldani et al. (2005) and Espinach Ros \& Sánchez (2006).

b) Megaspawner index (MI): This index proposed by Froese (2004) is indicative of how fishery could impact on population structure providing also insight into the potential for genetic variability and the abundance of large size spawners. The MI is defined as the ratio of fish larger than the megaspawner length to the number of fish larger than the legal size at first capture according to the following formula:

$\mathrm{MI}=$ Number of fish $>\mathrm{ML} /$ number of fish $>\mathrm{L}_{\mathrm{c}}$

where $\mathrm{ML}$ is the megaspawner length estimated as $\mathrm{L}_{\text {opt }}+$ $0.1 \mathrm{~L}_{\text {opt }}$ (Froese, 2004), with $\mathrm{L}_{\text {opt }}$ being the length at which a cohort maximizes its biomass and calculated as $\mathrm{L}_{\infty} * 3 /[3+(\mathrm{M} /$ $\mathrm{K})$ ] (Beverton \& Holt, 1957) and $\mathrm{L}_{\mathrm{c}}=42 \mathrm{~cm}$, corresponding to the legal size at first capture according to provincial regulations.

c) Fishing mortality (F): This parameter represents the instantaneous exponential rate at which fish are being removed by fishing and was estimated as $\mathrm{Z}-\mathrm{M}$, with $\mathrm{Z}$ being the instantaneous total mortality rate determined from analysis of previous length data (Boivin \& Minotti, 1990; Dománico \& Delfino, 1998; Oldani et al., 2005; Espinach Ros \& Sánchez, 2006) through the application of length converted catch curves (Pauly, 1990).

d) Exploitation rate (E): This parameter, computed as F/Z, represents the fraction of the total mortality attributable to fishing mortality (Sparre \& Venema, 1997).

e) Yield per recruit (Y/R): This analysis, performed with the Yield software (Hoggarth et al., 2006), identifies those values of fishing mortality and age or length at first capture that give the maximum yield per recruit from the fishery, thus enabling the recognition of growth overfishing.

f) Spawning potential ratio (SPR): The spawning potential ratio represents the number of mature eggs produced by an average recruit in a fished population, where density dependent growth and survival did not occur, divided by the number of mature eggs in an unfished population (Gabriel et al., 1989; Goodyear, 1993). This indicator helps to identify what minimum length and exploitation level thresholds may serve to prevent recruitment overfishing (Slipke et al., 2002) and as such is also appropriate for defining management goals when life history data are limited (Williams \& Schertzer, 2003). This indicator was calculated by means of the FAST software (Slipke \& Maceina, 2001).

\section{Results}

Fishing trends. The landing records compiled from 1935 to 2009 showed different patterns (Fig. 2). From 1935 to 1988 catches ranged from 6,000 to 23,000 tons per year with a mean of 15,047 tons $(\mathrm{SD}=5.29)$. Although highly variable, a decreasing trend can be observed. For this period, fish catches were allocated mostly to direct human consumption, oil production, and sales to local markets. Since 1994, however, the catches increased sharply, with the location of the first cold plants in the area. In 2001 currency exchange market conditions favored a heavy fishery exportation activity. This activity, promoted in turn, the settlement of additional cold plants, peaking sábalo catches around 40,000 tons by 2004 , with a mean catch of 29,490 tons $(\mathrm{SD}=10.09)$ for the period 2001-2009.

Hydrological analysis. On the basis of historic flow data, the Paraná River exhibited different hydrological and variable conditions. From 1920 to 1972 prevailed generally low CCI $($ mean $=0.37)$ and $\mathrm{FCI}($ mean $=0.05)$ values, with even a period (1944-1955) of very low flow exhibiting a CCI of 0.21 and FCI of 0.02. However, from 1972 to 1999 the Paraná River showed higher $\mathrm{CCI}($ mean $=0.72)$ and FCI (mean=0.26) values during a noticeable wet period including two large El Niño events (ENSO). During the 1999-2009 period, hydrology was dominated by a lack of regular flow pulses and almost absence of flooding conditions in the alluvial valley (Fig. 3). Accordingly, mean CCI and FCI values decreased to 0.39 and 0.04 respectively.

Potential yield estimation. For the study area the potential yield ranged from 18,000 to 24,000 tons for the sábalo after correction of the relative abundance depending on whether

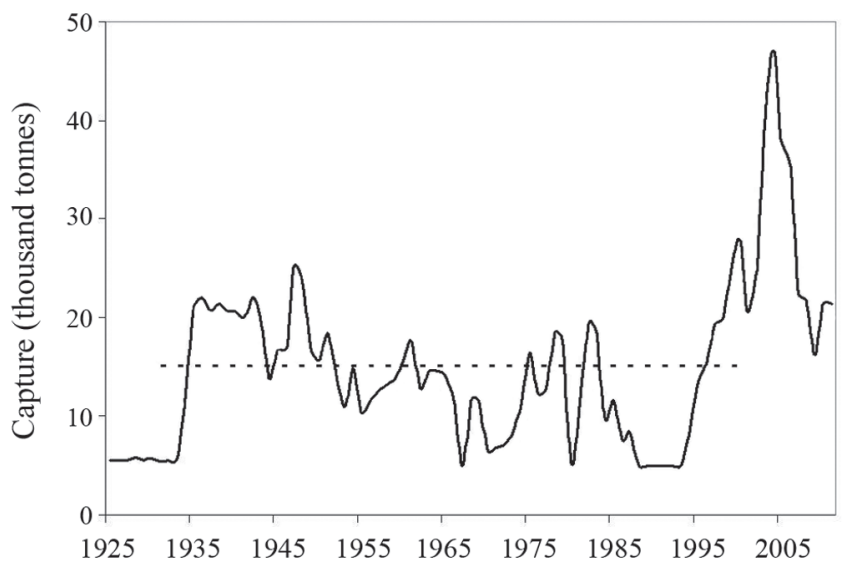

Fig. 2. Capture records of sábalo in the Paraná basin. The data taken from 1920 to 1988 were compiled by the National Agency of Freshwater Fisheries. The data from 1994 to 2009 correspond to the exportation records of the Sanitary National Service (SENASA). No data from 1988 to 1993 were available. 


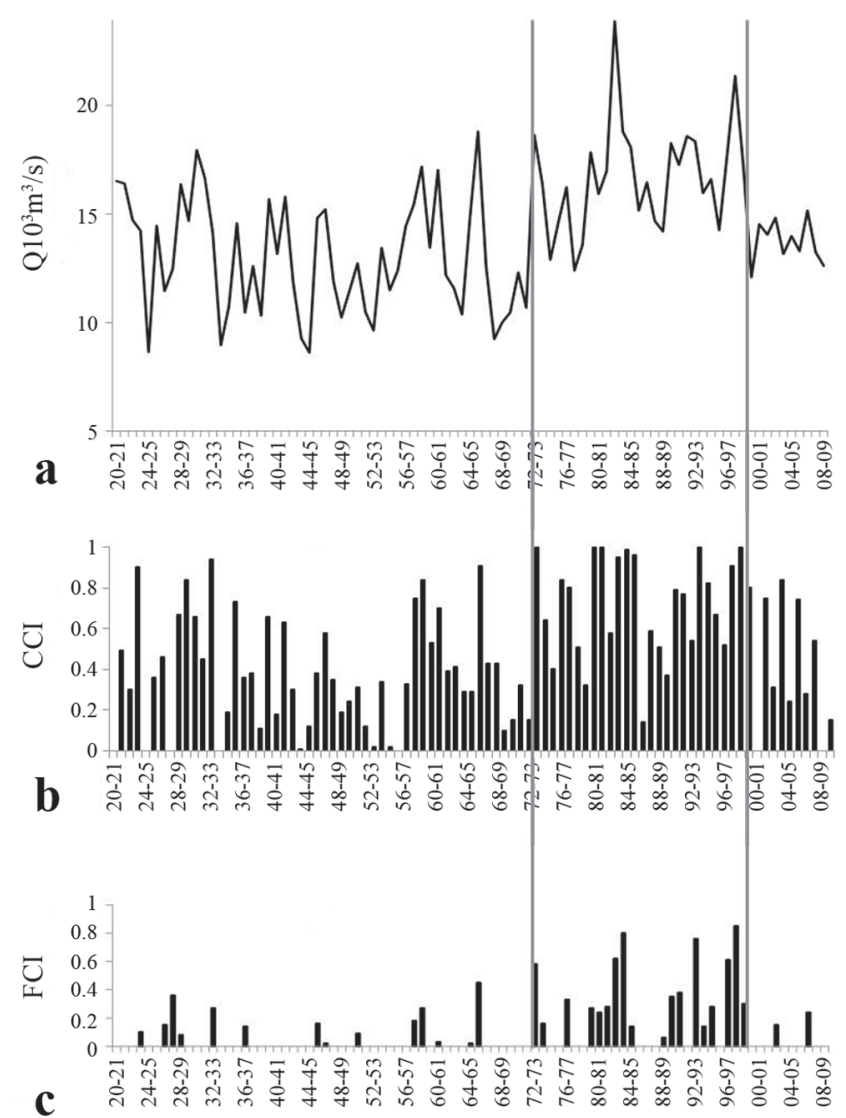

Fig. 3. a) Variation of average flow from 1920 to 2009. b) Variation in the channel-connectivity index (CCI) from 1920 to 2009, expressed as a percent of the time that the water level surpasses the bankfull level $(3 \mathrm{~m})$. c) Variation of the floodplain connectivity index (FCI) from 1920 to 2009 , expressed as the percentage of the time that the water level surpassed a height of $4.3 \mathrm{~m}$ flooding the alluvial valley. Vertical grey lines indicate different hydrological periods considered in this study.

the estimated maximum allowable catch was $30 \mathrm{~kg} / \mathrm{ha}$ or 40 $\mathrm{kg} / \mathrm{ha}$. Incorporating the precautionary factor correction, these figures represent 12 to $15 \mathrm{~kg} / \mathrm{ha}$, respectively. If we assume that an annual capture of 5,000 tons is needed for the consumption of the fishermen and to satisfy the demands of the local markets, a maximum of 7,000 to 10,000 tons would be available for exportation.

Population parameters and fishery status assessment. The estimated growth parameters were $\mathrm{L}_{\infty}=68.3 \mathrm{~cm}, \mathrm{~K}=0.28$, and $t_{0}=-0.2$. The first size at maturity was estimated at 37.1 $\mathrm{cm}$, thus defining a reproductive load value $\left(\mathrm{L}_{\mathrm{m}} / \mathrm{L}_{\infty}\right)$ of 0.54 and an $\mathrm{L}_{\mathrm{c}} / \mathrm{L}_{\infty}$ ratio of 0.61 . On the basis of these parameters, the $\mathrm{L}_{100}$ was calculated at $44 \mathrm{~cm}$. The natural mortality estimations differed according to the method used: Pauly (1980), 0.53; Hewitt \& Jones (2005), 0.38; Rikhter \& Efanov (1976), 0.60; Jensen (1996), 0.42; and Alagaraja (1984), 0.42; thus giving a mean value of 0.46 . Accordingly, the $\mathrm{M} / \mathrm{K}$ ratio ranged between 1.25 and 2.14, with the mean value of 1.64 falling within the expected range of the invariants of Beverton \& Holt (1957). On the basis of those data, the $\mathrm{L}_{\mathrm{opt}}$ was determined to be $44.5 \mathrm{~cm}$, which length corresponds to an age of 3.75 years, quite similar to the $\mathrm{L}_{100}$ value.

In addition, effort increase from 1978 to 2005 was illustrated by a shift in mean fish length from 48 to $42 \mathrm{~cm}$ and in maximum length from 66 to $54 \mathrm{~cm}$ along with a reduction in mesh size from 16 to $12 \mathrm{~cm}$ (Fig. 4).

The fishing mortality showed also an increasing trend, with a doubling of M occurring after 2001, and the MI exhibiting a strong reduction in parallel by 2005 (Table 1).

The yield per recruitment analysis indicated that growth overfishing was not observed but could be expected if fish smaller than $32 \mathrm{~cm}$ were captured (Fig. 5A). The spawning potential ratio analysis, however, showed that sábalo stocks became overfished as the exploitation rate increased or the legal size decreased (Fig. 5B). On the basis of an average natural mortality of 0.46 , a decreasing trend in SPR levels becomes evident with a notable drop below 0.3 occurring in 2005, particularly at Helvecia port, reflecting recruitment overfishing. With $42 \mathrm{~cm}$ as the first capture length, a maximum exploitation rate of $0.48(\mathrm{~F}=$ 0.67 ) is allowable in order to avoid a drop of the SPR below 0.3 . In contrast, if the first capture length is reduced to 38 $\mathrm{cm}$ - as happened in 2005- an exploitation rate of only 0.35 would be permissible.

In addition, the application of $\mathrm{F}$ as representative of fishing effort along with the value of SPR as a proxy for spawning stock biomass allowed a monitoring of the sábalo fishery trends and an assessment of how the fishery shifted from an underexploited to an overexploited state over time, so as to reach an overfished status from 2002 onwards (Fig. 6).

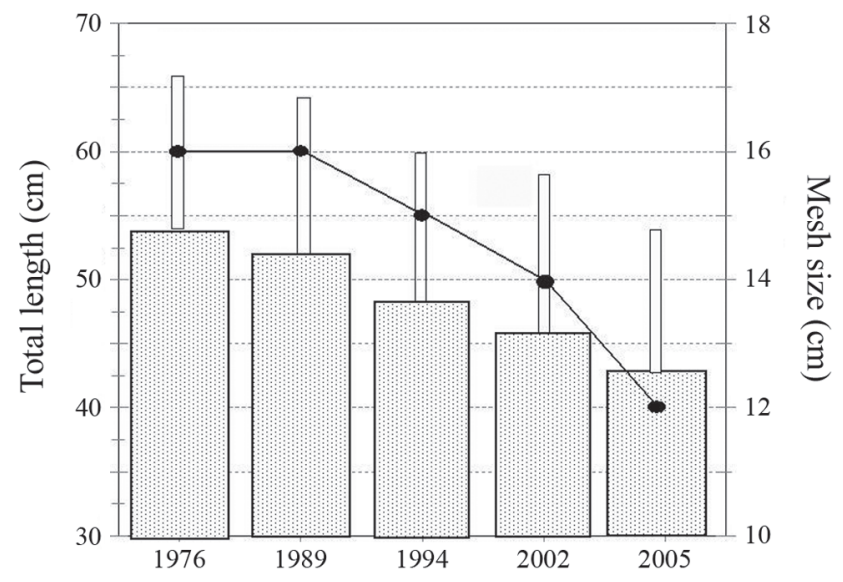

Fig. 4. Variation in the mean length (wide bars), the maximum length (thin bars), and the mesh size (points) between 1976 and 2005. 
Table 1. Fishing mortality (F), fishing mortality-natural mortality ratio $(\mathrm{F} / \mathrm{M})$, total mortality $(\mathrm{Z})$, exploitation ratio (E) and megaspawner index (MI) estimated for different fishery years in analyzed landing sites.

\begin{tabular}{ccccccc}
\hline Parameter & $\begin{array}{c}\text { Puerto } \\
\text { Sánchez }\end{array}$ & Victoria & Victoria & $\begin{array}{c}\text { Puerto } \\
\text { Sánchez }\end{array}$ & Helvecia & Victoria \\
& 1976 & 1989 & 1994 & 2002 & 2005 & 2005 \\
\hline F & 0.18 & 0.19 & 0.34 & 0.93 & 2.04 & 1.48 \\
F/M & 0.39 & 0.41 & 0.74 & 2.02 & 4.43 & 3.21 \\
Z & 0.64 & 0.65 & 0.80 & 1.39 & 2.5 & 1.94 \\
E & 0.29 & 0.29 & 0.43 & 0.67 & 0.82 & 0.76 \\
MI & 100 & 94 & 85 & 55 & 22 & 35 \\
\hline
\end{tabular}
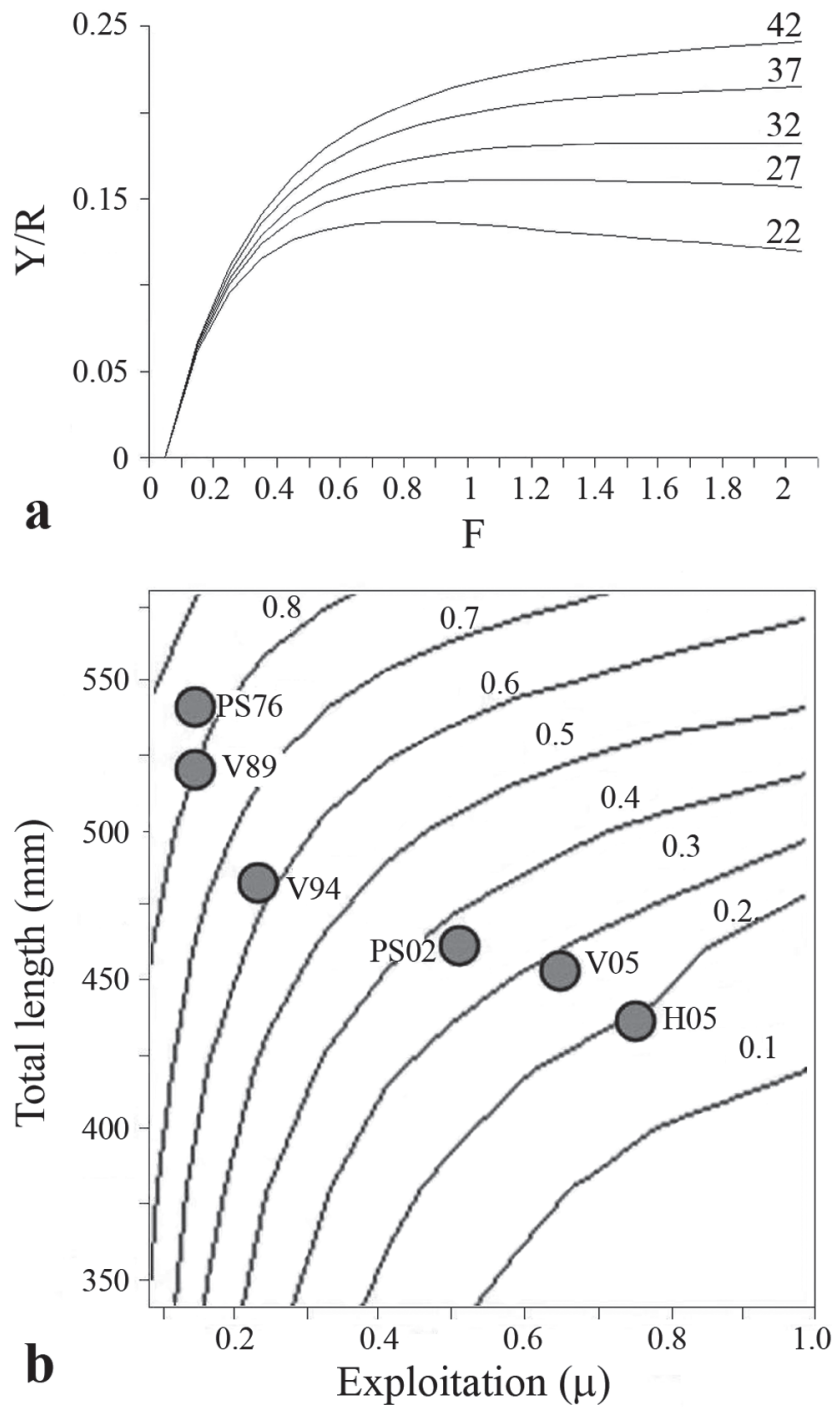

Fig. 5. a) Analysis of yield per recruitment for different size at first capture. b)Spawning potential ratio (SPR) over time based on the estimated exploitation rate $(\mu)$ and the capture length. PS76: Puerto Sánchez 1976; PS02: Puerto Sánchez 2002; V89: Victoria 1989; V94: Victoria 94; V05: Victoria 2005; H05: Helvecia 2005.

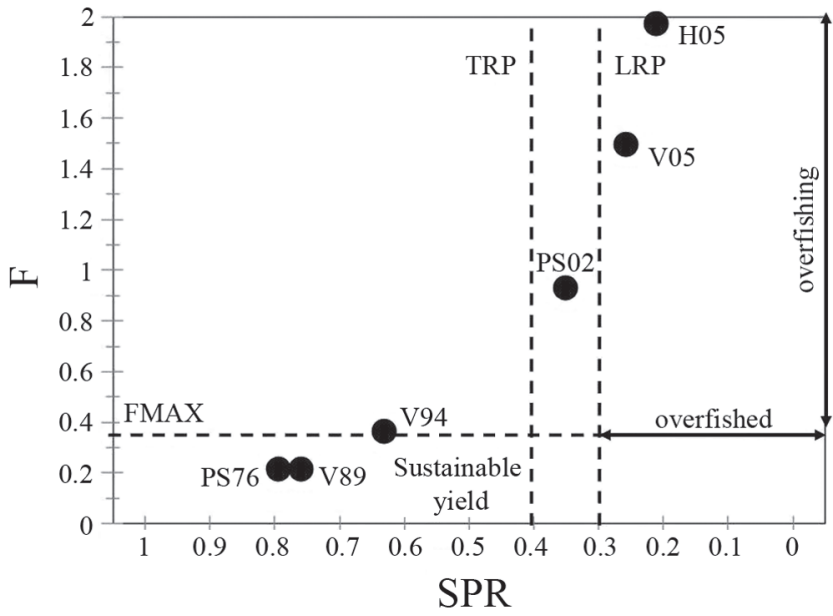

Fig. 6. Sábalo fishery status according to spawning potential ratio (SPR) and fishing mortality (F) variability across time. TRP: Target reference point; LRP: Limit reference point. PS76: Puerto Sánchez 1976; PS02: Puerto Sánchez 2002; V89: Victoria 1989; V94: Victoria 94; V05: Victoria 2005; H05: Helvecia 2005.

\section{Discussion}

The sábalo fisheries of this study constitute the first documented example within the Paraná River basin of a change in fish exploitation patterns assessed during contrasting hydrological conditions. We applied a combination of simple indicators that provided management clues within a context of the poor fishery data that usually occurs in most of the large Neotropical rivers. The assessment of historical trends indicated that this species had been subjected to a low to moderate level of artisanal fishing exploitation until 1995 (Quirós \& Cuch, 1989), but then became more intensively exploited after 2001 as the result of an exportation development by the commercial fisheries. The catch records from the 1935 to 2001 period suggested that a catch of 15,000 tons for both local consumption and exportation could be considered as an estimate for the maximum average yield and therefore close to the MSY (Caddy, 1999). Such value, however, was exceeded three times in 2004.

On the basis of these observations, we consider that the sábalo yield from the middle and lower Paraná River - although still within the context of healthy floodplains in those areas would be limited by climatic features and therefore be lower than would be predicted for several subtropical and tropical large rivers from South America as predicted by the empirical models of Valderrama \& Zarate, (1989), Bayley (1988), MRAG(1993) and Bayley \& Petrere (1998), or for tropical African rivers (Welcomme, 1985). Thus, a threshold value of 15,000 tons may represent a suitable candidate for defining an appropriate limiting catch reference point for the purpose of both consumption and exportation. 
Habitat hydrological indicators. A comprehensive understanding of the changes that have occurred in the sábalo fishery must also take into account the hydrological conditions as they influence on the larvae abundance (Fuentes \& Espinach Ros, 1998) and availability of nursery areas and recruitment (Agostinho et al., 1997; 2004; Gomes \& Agostinho 1997). Between 1972 and 1999 the Paraná basin experienced extremely wet conditions, particularly during the years 1982-1983 and 1997-1998 when very strong El Niño events took place. Nevertheless, after 1999 and throughout almost a decade, the annual flooding pulses were of low intensity due to low precipitations and also due to dam regulations in the upper Paraná basin, mainly during low flow conditions (Agostinho et al., 2007; Baigún et al., 2011). In the absence of data concerning relationships between flood pulse attributes and the annual recruitment levels or the density of juveniles in the alluvial valley, simple indices such as the CCI and FCI could be used as proxies of habitat connectivity and habitat availability for larval hatching and juvenile growth, with the expectation that the fish yield would increase after preadult recruitment two years later. Whereas the CCI reflects the potential to connect the main channel with the floodplain and is linked to the concept of amplitude proposed by Neiff (1997) to characterize pulse attributes, the CFI is more related to water residence time. Thus, the variation in CCI and FCI values could be used as indicative of whether poor or good recruitment conditions could be expected and, accordingly, how to regulate the fishing effort during the following years. Based on these analyses we suggest as preliminary guidelines considering a CCI of 0.4 and a FCI of 0.05 as threshold values that could reduce the probabilities of overfishing scenarios as was observed during the 1999 -2009 period, when fishing pressure increased along with a reduction in the river's flow. Such criteria, however, should be adjusted by more detailed studies based on assessing the relationship between recruitment intensity or juveniles density and flooding area and water residence time.

Biological and fishery indicators. A decrease in mean length was accounted for by an observed increase in catch after 1995 and particularly as the result of an uncontrolled exportation activity that took place from 2001 to 2006 . Alternatively, however, this diminution could also be explained by an increase in recruitment success through the extraordinary flooding during 1982-1983 and 1997-1998, as was proposed by Espinach Ros (2008). Nevertheless, the decrease in maximum length, consistent with the same trend in the mean length, suggests that fishing effort could have impacted on stock composition and abundance. As noted by Espinach Ros \& Sánchez (2006), during 2004 the commercial fisheries started harvesting fish of $38 \mathrm{~cm}$, implying that the corresponding changes in the gill net selectivity had resulted in the removal of a significant number of immature fish that were accordingly smaller than size at first maturation. We therefore support the notion that a minimum legal size of $42 \mathrm{~cm}$ is an appropriate catch limit, that length being close to both the $\mathrm{L}_{\text {opt }}$ and the $\mathrm{L}_{100}$. Such a minimum size would guarantee that recently recruited individuals in the fishery have the opportunity to reproduce completely at least once. Our estimation of $\mathrm{L}_{\mathrm{m}}$ was very close to the value (e.g., $36 \mathrm{~cm}$, females) determined by Espinach Ross and Sanchez (2006) and as such produced an $\mathrm{L}_{\mathrm{m}} / \mathrm{L}_{\infty}$ ratio within the expected range of the invariants suggested by Beverton and Holt (1957). The estimated growth parameters, however, differed since the asymptotic length was higher than the values assessed by previous studies on the Paraná River (Cordiviola de Yuan, 1971; Carozza \& Cordiviola de Yuan, 1991; Araya \& Sverlij, 1991; Espinach Ros \& Sánchez, 2006; Espinach, 2008). We believe, though, that a larger asymptotic value, as was obtained in this study, is more realistic since fish larger than $60 \mathrm{~cm}$ were not uncommon elsewhere in the Paraná before the onset of the exportation period (Boivin \& Minotti, 1990; Dománico \& Delfino, 1998; Oldani et al., 2005). Furthermore, at the Paraná-Paraguay confluence where the sábalo fishery is of secondary relevance, Bechara et al. (2007) reported sizes close to $70 \mathrm{~cm}$. According to Froese and Binohlan (2003), asymptotic length itself is highly correlated with the length of the largest individuals found in a given population, and therefore a close agreement should be expected between the two parameters.

The spawning potential ratio analysis showed that the recruitment overfishing problem was observed in 2005 in agreement with results previously obtained by Espinach Ros \& Sánchez (2006). Recruitment overfishing typically occurs when spawning biomass of the population is reduced, such that the number of recruits produced is not great enough to replenish the population. In addition, we support the notion that fish stocks became overfished since the fishing mortality in Helvecia area was up to five times higher than the natural one. Recruitment overfishing is by far the most deleterious cause of mortality since that type of overfishing favors a selective removal of the largest sized migratory individuals, thus resulting in a loss of genetic diversity and a reduction in the possibility of genotypic variability (Millner \& Whiting, 1996; Law, 2000).

In the Paraná River fishery impact was reflected in a trend toward smaller mean and maximum lengths and a decrease in the megaspawner proportion over time. A suggested range of SPR threshold values was proposed in the literature extending from $20 \%$ to $30 \%$ (Goodyear, 1993) or from $20 \%$ to $60 \%$, depending on the life history of a given fish (Mace \& Sissewine, 1993), and from $40 \%$ to $50 \%$ to prevent recruitment overfishing (Quist et al., 2002). The use of an SPR $=0.30$ has been considered equivalent to the maximum fishing mortality for attaining a maximum sustainable yield (i.e., the $\mathrm{F}_{\mathrm{MSY}}$; Restrepo et al., 1998), while a preservation of $30 \%$ of the unfished biomass could be appropriate even for stocks that can apparently maintain average recruitments at a lower biomass (Sainsbury, 2008). 
In the absence of a knowledge of the sábalo stockrecruitment relationship, and because of the hydrological variability present and our uncertainty concerning the natural mortality of the species, we propose using an SPR $=0.30$ as a limiting reference point, an $\mathrm{SPR}=0.40$ as a precautionary reference point, and an $\mathrm{SPR}=0.50$ as a target reference point. Within this context, the average exploitation rate $(\mu)$ for a sábalo fishery should not be greater than 0.40 (i.e., $\mathrm{F}=0.40$ ) in order to maintain the spawning biomass above the 0.30 threshold. Furthermore, an increase in the exploitation rate to 0.50 (at a corresponding $\mathrm{F}=0.67$ ) would promote recruitment overfishing unless the minimum legal size is increased to $43.5 \mathrm{~cm}$, which length is almost coincident with the $\mathrm{L}_{\text {opt }}$. In turn, a precautionary SPR value (i.e., 0.40) can be accomplished by maintaining an exploitation rate of 0.30 (at an $\mathrm{F}=0.40$ ), which figure is slightly below the average $\mathrm{M}$ value. To achieve the target value $(\mathrm{SPR}=0.5)$, however, would require an exploitation rate as low as 0.22 (at an $\mathrm{F}=$ 0.30 ). This $\mathrm{F}$ value is well below $\mathrm{M}$, thus representing an ideal condition for sustainability (Sainsbury, 2008). This status, however, is probably not achievable because of current fishing demands in contrast to the low fishing pressure scenario observed several decades ago. Nevertheless, the SPR analysis indicated that if the legal size were reduced to $38 \mathrm{~cm}$, a limiting SPR would then be achieved by applying an exploitation rate of 0.33 (at an $\mathrm{F}=$ 0.44 ), whereas a precautionary SPR would require an exploitation rate of 0.25 , equivalent to an $F=0.34$. That value for fishing mortality, however, was almost tripled in 2002, when fish of $38 \mathrm{~cm}$ were captured, thus indicating that fishing based on that legal catch limit would become unsustainable unless the fishing mortality were drastically reduced to levels observed before 1994.

In addition, the combined use of the $\mathrm{F}$ and SPR values indicated that in 2002 the fishery almost reached the precautionary value of SPR $=0.40$ within the context of conditions producing an increasing $\mathrm{F}$, which circumstance should have been considered as a warning signal for the coming years. An increase in the fishing effort to comply with exportation demands favored a harvest of the largest individuals so as the megaspwaner proportion decreased; this change occurred in conjunction with a shift in the mesh size that resulted in an overfished status in 2005 (SPR $<0.30)$. Therefore, on the basis of SPR analyses, the regulation of minimum catch size should be determined by considering the $\mathrm{L}_{\text {opt }}(44 \mathrm{~cm})$ as a target reference point and the current $\mathrm{L}_{\mathrm{C}}(42 \mathrm{~cm})$ as the limiting reference point instead of the classical $\mathrm{L}_{\mathrm{m}}$ that is usually considered for most fishing regulations. These new criteria will enhance the availability survival of the larger individuals, avoid the capture of immature fish, and reduce the potential for bycatch that exists with the use of smaller mesh sizes. We are certainly aware that some of these reference indicators are more appropriately applicable to the management of fisheries that are found under equilibrium conditions, with a constant recruitment and natural mortality rate, which circumstance is probably not common for most fish stocks (Myers et al., 1995). Nevertheless, classical stock assessments based on the yield per recruitment have been applied in large rivers (Petrere, 1983; Bayley \& Petrere, 1989; Mateus \& Petrere, 2004; Dei Tos, 2009). Moreover, we suggest that this approach could be useful to diagnose overfishing conditions and overfished stocks based on the minimum legal length and the fishing mortality rates during wet or dry decadal periods, that are recurrent in the Paraná basin. Nevertheless, future efforts should be devoted to a confirmation of these reference points and to adapting them to these different hydrological conditions, mainly in view of predicted climate changes.

Values of natural mortality also provided clues about the potential for exploitation (Quinn \& Derisso, 1999). For example, lower values for $\mathrm{M}(0.12-0.19)$ have been proposed by Espinach Ros (2008) based on alternative growth parameter estimations obtained through otolith analysis $\left(\mathrm{L}_{\infty}=\right.$ $54 \mathrm{~cm}, \mathrm{~K}=0.08 ; \mathrm{t}_{\mathrm{o}}=-11.1$ ). Those results indicate that an allowable fishing mortality could be even lower than we are proposing here, since for fixed $\mathrm{M} / \mathrm{K}$ and $\mathrm{L}_{\mathrm{c}}$ values the maximum yield as a fraction of the size of the unexploited fishable stock is nearly directly proportional to $\mathrm{M}$ (Beddington \& Kirkwood, 2005).

Management caveats. The example of sábalo fisheries in the Paraná River and other related species belonging to the Prochilodontidae inhabiting other Neotropical river basins suggests that new management criteria are needed to envision long term sustainable fisheries. Simple indicators based on length structure monitoring, common fish biological characteristics - such as growth parameters, natural mortality, and reproductive patterns - and basic fishery information, coupled to hydrological information, can be integrated and used to follow fishery trends and to predict how management directions could affect stock sustainability.

We claim that fisheries in large rivers need to be managed in accordance with an ecosystem-oriented approach since the fish production is linked to key components related to fluvial functioning, structure, and ecological processes. Baigún et al. (2008), for example, emphasized the need to protect the hatching and growth areas in the alluvial valleys and highlighted the importance of maintaining appropriate levels of detritivorous species. Such species are a characteristic and salient feature of Neotropical rivers and contribute to nutrient recycling and the regulation of carbon transport in rivers (Winemiller et al., 2006; Taylor, 2006), thus the stock composition and abundance of those species can serve as valuable indicators of ecosystem health. Within this context, traditional guidelines based on optimizing opportunistic or short term financial profits by strongly removing a large biomass of ecological valuable species, or preferentially capturing the largest individuals, represents an unsustainable approach mostly related to conventional management criteria. 
Espinach Ros \& Sanchez (2006), following Winemiller \& Rose (1992) classification, pointed out that the sábalo can be considered to be a periodic strategist as it is adapted to changing environmental conditions by delaying maturity, producing large egg numbers, and undergoing synchronous spawning during favorable periods and in suitable reproductive habitats. That life strategy under the proper hydrological conditions could accordingly promote notable recruitment pulses and more vigorous cohorts that could, in turn, sustain a long term higher yield (Espinach Ros \& Sanchez, 2006). Although this assertion could merit credibility, we suggest that the biomass surplus derived from years of intense flooding pulses and high recruitments should nevertheless be exploited with caution. Natural density dependent recruitment processes, as predicted by stock-recruitment relationships, could be expected at some very high stock density, with the implication that an extremely high spawner biomass would not necessarily guarantee a better recruitment and a correspondingly higher yield. Instead, we propose that a higher biomass production should be envisioned - and accordingly treated - as a buffering mechanism to maintain suitable biomass population levels during less favorable hydrological periods, that were not uncommon in the Paraná River and lasted one or more decades. As periodic strategists, the sábalo could also generate weak cohorts and even suffer a high mortality in the precruitment phase during those years when flood pulses are weak, thus making the regulation of fishing mortality during those periods a critical management consideration. On the other hand, highly abundant species, such as Prochilodus spp. or the related Semaprochilodus spp., inhabiting other basins can also be impacted under an uncontrolled fishing pressure, as was recently shown for the Amazon River (Lambert \& Petrere, 2006), the Orinoco River (Novoa, 2002), and the Magdalena River (Galvez \& Mojica, 2007). Moreover, as pointed out by Anderson et al. (2009), the overfishing of the Prochilodus species is a pervasive problem in much of the Amazon and Orinoco basins as a result of its notable economic significance and, as such, presents one of the greatest challenges to fishery management in those regions. As noted by Shelton \& Mangel (2011), high environmental variation dramatically alters the consequences of exploitation as could be the case in large floodplain-rivers.

Whereas periodic species could have a high potential for recovery from overfishing, a long term and precautionary viewpoint should definitely be considered in harvesting only a certain fraction of the surplus production and for the preservation of large size individuals rather than permitting an uncontrolled heavy and opportunistic exploitation, considering fishery resources as only of commodity values. Unfortunately, the opening of a major commercial fishery after 2001 was accompanied neither by the appropriate fishery studies nor by an analysis of the socioeconomic benefits for fishermen and their communities, triggering also conflicts among different stakeholders. We conclude that if exportation fishery is to be properly maintained, management policies should take into account the expected variation in the hydrological regime, particularly in view of incoming climate changes, the natural production of the fluvial system, the life history traits of the species, the impacts of fishing, including the bycatch effects, and the socioeconomic requirements of fishermen, all of these considerations being key elements in the preservation of fishery sustainability.

\section{Acknowledgments}

The authors are thankful to Miguel Petrere and Robin Welcomme for critical review of manuscript as well as for their valuable suggestions. The authors wish also to thank Donald F. Haggerty for editing the final version of the manuscript.

\section{Literature Cited}

Agostinho, A. A., H. F. Júlio, L. C. Gomes, L. M. Bini \& C. S. Agostinho. 1997. Composição, abundância e distribuição espaço-temporal da ictiofauna. Pp. 179-208. In: Vazzoler, A. E., A. A. Agostinho \& N. S. Hahn (Eds.). A planície de inundação do alto rio Paraná: aspectos físicos, biológicos e socioeconômicos. EDUEM/UEM, Nupelia, Maringá, Brazil.

Agostinho, A. A., L. C. Gomes, H. I. Suzuki \& H. F. Julio Jr. 2003. Migratory fishes of the Paraguay-Paraná basin, Brazil. Pp. 1999. In: Carolsfeeld, J., B. Harvey, C. Ross \& A. Baer (Eds.). Migratory fishes of South America. Biology, fisheries and conservation status. World Fisheries Trust/World Bank/IDRC 2004.

Agostinho, A. A., L. C. Gomes, S. Veríssimo \& E. K. Okada. 2004. Flood regime and fish: effects on spawning, recruitment and attributes of the assemblages in the Upper Paraná River floodplain. Reviews in Fish Biology and Fisheries, 14: 11-19.

Agostinho, A. A., F. M. Pelicice, A. C. Petry, L. C. Gomes \& H. F. Julio Jr. 2007. Fish diversity in the upper Paraná River basin, management and conservation. Aquatic Ecosystem Health and Management, 10: 174-186.

Alagaraja, K. 1984. Simple methods for estimation of parameters for assessing exploited fish stocks. Indian Journal of Fisheries, 31: 177-208.

Anderson, E. P., M. Montoya, A. Soto, H. Flores \& M. E. McClain. 2009. Challenges and opportunities for co-management of a migratory fish, Prochilodus nigricans, in the Peruvian Amazon. American Fisheries Society Symposium 69: 741-756.

Araya, P. \& S. B. Sverlij. 1999. Edad y crecimiento de Prochilodus scrofa (Steindachner, 1881) Pisces, Prochilodontidae, en un tramo del alto río Paraná (Misiones, Argentina). Iheringia, Série Zoologia, 86: 45-54.

Baigún, C., A. Puig, P. G. Minotti, P. Kandus, R. Quintana, R. Vicari, R. Bo, N. Oldani \& J. Nestler. 2008. Resource use in the Paraná River delta (Argentina): moving away from an ecohydrologicalal approach? Ecohydrology and Hydrobiology, 8: 245-262.

Baigún, C., N. O. Oldani \& P. Van Damme, P. 2011. Represas hidroeléctricas en América Latina y su impacto sobre la ictiofauna. Pp. 395-415. In: Van Damme, P. A., F. Carvajal \& J. 
Molina (Eds.). Peces de la Amazonía boliviana: potencialidades y amenazas. INIA, Cochabamba.

Bayley, P. B. 1988. Accounting for effort when comparing tropical fisheries in lakes, river-floodplain and lagoons. Limnology and Oceanography, 33: 963-972.

Bayley, P. B. \& M. Petrere. 1989. Amazon fisheries assessment of methods, status and management options. Pp. 385-398. In: Dodge, D. P. (Ed.). Proceedings of the international large river symposium. Canadian Special Publication of Fisheries and Aquatic Sciences 106, Ottawa.

Bechara, J., F. Vargas \& C. Flores Quintana. 2007. Biología pesquera de las principales especies de importancia económica en el área de la confluencia de los ríos Paraná-Paraguay. Informe final presentado por el Instituto de Ictiología del Noreste de la Facultad de Ciencias Veterinarias de la UNNE a la Subsecretaría de Pesca y Acuicultura de la Nación. Available from: http://www.minagri.gob.ar/site/pesca/pesca_continental/04=informes/02-alta cuenta parana-plata/ archivos/000001 (Julio 2011).

Beddington, J. R. \& G. P. Kirkwood. 2005. The estimation of potential yield and stock status using life-history parameters. Philosophical Transactions of the Real Society, 360: 163-170.

Béné, C., G. Macfadyen \& E. H. Allison. 2006. Increasing the contribution of small scale fisheries to poverty alleviation and food security. FAO Fisheries Technical Paper 481, Rome.

Berkes, F., R. Mahon; P. McConney, R. C. Pollnac \& R. S. Pomeroy. 2001. Managing small-scale fisheries: Alternative directions and methods. Ottawa: International Development Research Centre. Available from: www.idrc.ca/booktique (April 2012).

Beverton, R. J. \& S. J. Holt. 1957. On the dynamics of exploited fish population. U.K. Ministry of Agriculture and Fisheries, Fisheries Investigations (Ser II) 19.

Boivin, M. \& P. G. Minotti. 1990. Estudio integral sobre las características y el aprovechamiento de la fauna ictícola en la zona de islas del Departamento de Victoria, Entre Ríos. Informe Final, Convenio Consejo Federal de Inversiones, Gobierno de Entre Ríos.

Bonetto, A. A., E. Cordiviola de Yuan \& C. Pignalberi. 1970. Nuevos datos sobre poblaciones de peces en ambientes permanentes del Paraná Medio. Physis, 30: 141-154.

Caddy, J. F. 1999. Deciding on precautionary management measures for stock based on a suite of limit reference points (LRPs) a basis for a mult-LRP harvest law. Northwest Atlantic Fisheries Organization. Science Council Studies, 32: 55-68.

Carozza, C. \& E. Cordiviola de Yuan. 1991. Estudios ictiológicos en la laguna la Cuarentena (Isla Carabajal) río Paraná, Argentina: edad y crecimiento del "sábalo" Prochilodus lineatus Val. período 1984-1985 (Pisces, Curimatidae). Revue Hydrobiologie Tropicale, 24: 229-129.

Cordiviola de Yuan, E. 1971. Crecimiento de peces del Paraná medio. I. "sábalo" (Prochilodus platensis Holmberg) Pisces Tetragonopteridae. Physis, 30: 483-504.

Dománico, A. \& R. Delfino. 1998. Pesquerías del sábalo (Prochilodus lineatus) en la zona de Victoria, Entre Ríos (32 $\left.40^{\circ} \mathrm{S}, 60^{\circ} 10^{\prime} \mathrm{W}\right)$. Natura Neotropicalis, 29: 127-136.

Dei Tos, C., L. C. Gomes, A .A. Agostinho \& R. P. Batista. 2009. Age, growth, mortality and yield per recruit of the dourado Salminus brasiliensis, Corumbá Reservoir, Goiás State, Brazil. Neotropical Icthyology, 7: 223-230.

Drago, E. C. 2007. The physical dynamics of the river-lake floodplain system. Pp. 83-122. In: Iriondo, M. H., J. C. Paggi \& M. J. Parma (Eds.). The middle Paraná River. Limnology of a subtropical wetland, Springer Verlag, Berlin Heidelberg.
Espinach Ros, A. 2008. Proyecto evaluación del recurso sábalo (Prochilodus lineatus) en el Paraná. Informe de los resultados de la segunda etapa. Secretaría de Agricultura, Ganadería, Pesca y Alimentos Subsecretaría de Pesca y Acuicultura, Buenos Aires, Argentina. Available from: http://www.minagri.gob.ar/site/pesca/index.php (March 2012).

Espinach Ros, A. \& R. P. Sánchez. 2006. Proyecto de evaluación del recurso sábalo en el Paraná. Informe de los resultados de la primera etapa (2005-2006) y medidas de manejo recomendadas. Secretaría de Agricultura Ganadería, Pesca y Alimentación. Serie Pesca y Acuicultura: Estudios e Investigaciones Aplicadas Nro 1, Buenos Aires, Argentina. Available from: http://www.minagri.gob.ar/site/pesca/ index.php (March 2012).

Fabre, N. N. \& R. Barthem. 2005. O manejo da pesca do grandes bagres migradores: piramutaba e dourada no eixo SolimõesAmazonas / Manaus, Coleção Documentos Técnicos, Estudos Estratégicos, Ibama, ProVárzea.

Froese. R. 2004. Keep it simple: three indicators to deal with overfishing. Fish and Fisheries, 3: 86-91.

Froese, R. \& C. Binohlan. 2000. Empirical relationships to estimate asymptotic length, length at first maturity and length at maximum yield per recruit in fishes, with a simple method to evaluate length frequency data. Journal of Fish Biology, 56: 758-773.

Froese, R. \& C. Binohlan. 2003. Simple methods to obtain preliminary growth estimated for fish. Journal of Applied Icthyology, 19: 376-379.

Fuentes, C. M. \& A. Espinach Ros. 1998. Variación de la actividad reproductiva del sábalo Prochilodus lineatus (Valenciennes, 1847) estimada por el flujo de larvas en el río Paraná inferior. Natura Neotropicalis, 29: 25-32.

Gabriel, W. L., M. P. Sissenwine \& W. J. Overholtz. 1989. Analysis of spawning stock biomass per recruit: an example for George Bank Haddock. North American Journal of Fisheries Management, 9: 383-391.

Galvis, G. \& J. I. Mojica. 2007. The Magdalena River fresh water fishes and fisheries. Aquatic Ecosystem Health and Management, 10: 127-139.

Gomes, L. C. \& A. A. Agostinho. 1997. Influence of the flooding regime on the nutritional state and juvenile recruitment of the curimba, Prochilodus scrofa, Steindachner in upper Paraná River, Brazil. Fisheries Management and Ecology, 4: 263-274.

Goodyear, C. P. 1993. Spawning stock biomass per recruit in fisheries management: foundation and current use. Pp. 67-71. In: Smith, S. J., J. J. Hunt \& D. Rivard (Eds.). Risk evaluation and biological reference points for fisheries management. Canadian Journal of Fisheries and Aquatic Sciences Special Publication 120, Otawa.

Gulland, J. A. \& L. K. Boerema. 1973. Scientific advice on catch levels. Fisheries Bulletin, 71: 325-35.

Hewitt, D. A. \& J. M. Hoenig. 2005. Comparison of two approaches for estimating natural mortality based on longevity. Fishery Bulletin, 103: 433-437.

Hoggarth, D. D., S. Abeyasekera, R. I. Arthur, J. R. Beddington, R. W. Burn, A. S. Halls, G. P. Kirkwood, M. McAllister, P. Medley, C. C. Mees, G. B. Parkes, G. M. Pilling, R. C. Wakeford \& R. L. Welcomme. 2006. Stock assessment for fishery management. A framework guide to the stock assessment tools of the fisheries management science program (FMSP). FAO Fisheries Technical Paper 487, Rome. 
Isaac, V. J. \& M. L. Rufino. 1996. Population dynamics of tambaqui, Colossoma macropomum Cuvier, in the Lower Amazon, Brazil. Fisheries Management and Ecology, 3: 315-333.

Jensen, A. L. 1996. Beverton and Holt life history invariants result from optimal trade-off of reproduction and survival. Canadian Journal of Fisheries and Aquatic Sciences, 53: 820-822.

Lambert, M. C. \& M. Petrere Jr. 2006. Fisheries ecology and management of the Jaraqui (Semprochilodus taeniurus, $S$. insignis) in central Amazonia. Regulated River Research and Management, 5: 195-215.

Law, R. 2000. Fishing, selection and phenotypic evolution. ICES Journal of Marines Sciences, 57: 659-668.

Mace, P. M. \& M. P. Sissenwine. 1993. How much spawning per recruit is enough? Pp. 101-118. In: Smith, S. J. \& D. Rivard (Eds.). Risks evaluations and biological reference points. Canadian Special Publication of Aquatic Sciences, 120, Ottawa.

Mateus, L. A. \& M. Petrere Jr. 2004. Age, growth and yield per recruit of the pintado Pseudoplatystoma corruscans (Agassiz 1829) in the Cuiaba River basin, Pantanal Matogrossense, Brazil. Brazilian Journal of Fish Biology, 64: 257-264.

MRAG. 1993. Synthesis of simple predictive models for tropical river fisheries. Fisheries management science program. Overseas Development Administration. MRAG, Ltd.

Millner, R. S. \& C. L. Whiting. 1996. Long-term changes in growth and population abundance of sole in the North Sea from 1940 to the present. ICES Journal of Marine Sciences, 53: 1185-1195.

Myers, R. A., N. J. Barrowman, J. A. Hutchings \& A. A. Rosenberg. 1995. Population dynamics of exploited fish stocks at low population levels. Science, 269: 1106-1108.

Neiff, J. J. 1999. El régimen de pulsos en ríos y grandes humedades de Sudamérica. Pp. 97-146. In: Malvárez, I. (Ed.). Tópicos sobre humedales subtropicales y templados de Sudamérica. Universidad de Buenos Aires, Argentina.

Novoa, D. F. 1989. The multispecies fisheries of the Orinoco River. Development, present status and management status. Pp. 422428. In: Dodge, D. P. (Ed.). Proceedings of the international large river symposium. Canadian Special Publication of Fisheries and Aquatic Sciences 106, Ottawa.

Novoa, D. 2002. Los recursos pesqueros del eje fluvial OrinocoApure: presente y futuro. Ministerio de Agricultura y Tierras (MAT)-Instituto Nacional de Pesca y Acuicultura (INAPESCA), Caracas.

Oldani, N., M. Peña, M. \& C. Baigún. 2005. Cambios en la estructura del stock de peces de Puerto Sánchez en el cauce principal del tramo medio del río Paraná (1976-1977; 1984-1986 y 20022003). Pp. 67-88. In: Peteán, J. \& J. Cappato (Org.). Humedales fluviales de América del Sur. Hacia un manejo sustentable. Fundación Proteger, Santa Fe.

Pauly, D. 1980. On the interrelationship between natural mortality, growth parameters, and mean environmental temperature in 175 fish stocks. ICES Journal of Marine Sciences, 39: 175-192.

Pauly, D. 1990. Length-converted catch curves and the seasonal growth of fishes. Fishbyte, 8: 24-29.

Petrere Jr, M. 1983. Yield per recruit of the tambaqui, Colossoma macropomum Cuvier, in the Amazonas State, Brazilian Journal of Fish Biology, 22: 133-144.

Petrere, M., R. B. Barthem, E. A. Cordoba \& B. C. Gomes. 2004. Review of the large catfish fisheries in the upper Amazon and the stock depletion of piraiba (Brachyplatystoma filamentosum Lichtenstein). Reviews in Fish Biology and Fisheries, 14: 403-414.
Quinn, T. J. II \& R. B. Deriso. 1999. Quantitative fish dynamics. Oxford University Press, New York.

Quirós, R. 2004. The La Plata river basin: international basin development and riverine fisheries. Pp. 263-272. In: Welcomme, R. \& T. Petr (Eds.). Proceedings of the second international symposium on the management of large rivers for fisheries. FAO Regional Office for Asia and the Pacific, Volume I, RAP Publication 2004/16), Bangkok, Thailand.

Quirós, R. \& S. Cuch. 1989. The fishery of the lower Plata River basin: fish harvest and limnology. Pp. 362-378. In: Dodge, D. P. (Ed.). Proceedings of the international larger river symposium. Canadian Special Publication of Fisheries Aquatic Sciences 106, Ottawa.

Quist, M. C., C. S. Guy, M. A. Pegg, P. J. Braaten, C. L. Pierce \& V. T. Travnichek. 2002. Potential influence of harvest of shovelnose sturgeon population in the Missouri River system. North American Journal of Fisheries Management, 22: 537-549.

Restrepo, V. R., G. G. Thompson, P. M. Mace, W. L. Gabriel, L. L. Low, A. D. MacCall, R. D. Methot, J. E. Powers, B. L. Taylor, P. R. Wade \& J. F. Witzig. 1998. Technical guidance on the use of precautionary approaches to implementing national standards of the Magnuson-Stevens Fishery Conservation and Management Act. National Oceanic and NOAA Technical Memorandum, NMFS-F/SPO-31.

Rikhter, V. A. \& V. N. Efanov. 1976. On one of the approaches to estimation of natural mortality of fish populations. ICNAF Research Document 76/VI/8.

Sainsbury, K. 2008. Best practice reference points for Australian fisheries. Report to the Australian Fisheries Management Authority and the Department of the Environment, Water, Heritage and the Arts, Canberra. Available from: www.afma.gov.au/research/reports/ 2008/rep_sainsbury_bestpractice_jan08_20080228.pdf(December 2010).

Shelton, A. O. \& M. Mangel. 2011. Fluctuations of fish populations and the magnifying effects of fishing. Proceedings of the National Academy of Sciences of the United States of America, 108: 7075-7080.

Slipke, J. W. \& M. J. Maceina. 2001. Fishery analyses and simulation tools (FAST 2.0), Alabama, Auburn University.

Slipke, J. W., A. D. Martin, J. Pitilo Jr. \& M. Maceina. 2002. Use of the spawning ratio for the Upper Mississippi River channel catfish fishery. North American Journal of Fisheries Management, 22: 1295-1300.

Sparre, P. \& S. C. Venema. 1997. Introduction to tropical fish stock assessment. Part 1. Manual. FAO Fisheries Technical Paper 306.1, Rev. 2, Rome.

Sverlij, S. B., A. Espinach Ros \& G. Orti. 1993. Sinopsis de los datos biológicos y pesqueros del Sábalo Prochilodus lineatus (Valenciennes, 1847). FAO Sinopsis sobre la Pesca 154, Roma.

Taylor, B., A. S. Flecker \& R. O. Hall. 2006. Loss of a harvested fish species disrupts carbon flow in a diverse tropical river. Science, 313: 833-836.

Valderrama, M. \& M. Zárate. 1989. Some ecological aspects and present state of the fishery of the Magadalena River basin, Columbia, South America. Pp. 409-421. In: Dodge, D. P. (Ed.). Proceedings of the international larger river symposium. Canadian Special Publication of Fisheries and Aquatic Sciences 106, Ottawa.

Welcomme, R. L. 1985. River Fisheries. FAO Fisheries Technical Paper 262, Rome.

Welcomme, R. L. 1989. Review of the present state of knowledge of fish stock and fisheries of African Rivers. Pp. 515-532. In: 
Dodge, D. P. (Ed.). Proceedings of the international larger river symposium. Canadian Special Publication of Fisheries and Aquatic Science 106, Ottawa.

Welcomme, R. L., C. Béné, C. A. Brown, A. Arlington, P. Dugan, J. M. King \& V. Sugunan, V. 2006. Predicting the water requirements of river fisheries. Pp. 123-154. In: Verhoeven, J. T., B. Beltman, R. Bobbink \& D. F. Whigham (Eds.). Wetlands and natural resource management. Springer Verlag, Berlin Heidelberg.

Williams, E. H. \& K. W. Shertzer. 2003. Implications for life-history invariants for biological reference points used in fishery management. Canadian Journal of Fisheries Management, 60: 710-720.

Winemiller, K. O. \& K. A. Rose. 1992. Patterns of life-history diversification in North American fishes: implications for population regulation. Canadian Journal of Fisheries and Aquatic Sciences, 49: 2196-2218.

Winemiller, K. O., J. V. Montoya, D. L. Roelke, C. A. Layman \& J. B. Cotner. 2006. Seasonally varying impact of detritivorous fishes on the benthic ecology of a tropical floodplain river. Journal of North American Benthological Society, 25: 250-262.

Submitted November 25, 2011

Accepted December 11, 2012 by Fernando Mayer Pelicice Published March 31, 2013 